\title{
Estímulo para Isildinha Baptista Nogueira ${ }^{1}$
}

Uma das pioneiras da SBPSP, a psicanalista Virginia Bicudo, filha de pai negro e mãe branca, viveu na família e na própria pele as questões do racismo.

Em um meio predominantemente de homens brancos, ela desenvolveu em 1945 sua tese em Ciência Sociais Estudo de Atitudes Raciais de pretos e mulatos em São Paulo, onde contrariava a visão de seu orientador Donald Pierson, de que no Brasil a ascensão social anulava as marcas raciais. Em seu estudo, Virginia demonstrou que mesmo quando diminuem as diferenças sociais, o preconceito de cor permanece.

Em 1950, a convite da UNESCO, Virginia desenvolve um trabalho cujos objetivos eram "evidenciar os sentimentos e os mecanismos psíquicos de defesa manifestos nas atitudes relacionadas a cor" entre alunos de escolas públicas em São Paulo. Ela observa que o preconceito não aparece nas entrevistas e conclui, mostrando já o seu pensamento de psicanalista, que "os sentimentos hostis relacionados com a cor podem ter sido censurados, e portanto camuflados" (Bicudo, 1955, apud Maio, 2010). Neste estudo ela demonstra a dificuldade dos grupos "de cor" elevarem seu status educacional e profissional, sendo sua única opção o "branqueamento" de cor e de personalidade para ser aceito.

Ainda que Virginia seja lembrada por introduzir em seu pensamento psicanalítico a vertente social e demonstrar que os efeitos daninhos do racismo são transgeracionais, muitos a acusam de ter "branqueado". Recentemente Fabiana Cozza sofreu um confronto ao ser convidada para interpretar o papel de D. Ivone Lara, por questões de colorismo. E no dia 29 de Maio a rede Starbucks nos EUA fechou todas as suas lojas para um treinamento antirracismo, depois de uma atitude de discriminação contra dois homens negros em uma filial na Filadélfia.

O recém publicado Dicionário da Escravidão e da Liberdade utiliza a palavra "escravizado", para se referir àqueles que se costumava chamar de escravo, uma mudança que evidencia o aspecto violento e compulsório da vinda de negros ao Brasil, para significar o fenômeno da escravidão. Fato que sofre um processo de negação, como o preconceito.

Fatos e relatos que evidenciam que a violência e a discriminação racial permanecem ativas nas entranhas da sociedade. Como a Psicanálise pode contribuir para trazer à luz novos entendimentos e transformações nas questões de preconceito?

\footnotetext{
${ }^{1}$ Este estímulo foi preparado pela comissão organizadora do I Simpósio Bienal "O mesmo, o outro: Psicanálise em movimento" da Sociedade Brasileira de Psicanálise de São Paulo, para o "Fórum Violência e alteridade:.
} 